\title{
Language learning and teaching
}

THEORY AND PRINCIPLES See also abstracts 76-204, -210

76-185 Emons, Rudolf. Linguistik und Fremdsprachenunterricht: Vorüberlegungen $\mathrm{zu}$ einer pädagogischen Grammatik. [Linguistics and foreign language teaching: preliminary thoughts for a pedagogic grammar.] Praxis (Dortmund), 22, 4 (1975), 341-6.

The present state of research in foreign-language teaching is characterised by an abundance of different hypotheses about the relationship between linguistics and other disciplines such as psychology, learning theory, etc. It is worthwhile to set up first of all some general principles and guidelines rather than defining a pedagogic grammar. Usually a close connection is posited between a linguistic theory and learning method, e.g. pattern practice is usually linked with stimulusresponse learning theory. However, the relationship between a linguistic theory and a teaching model is indirect. Although most pedagogic grammars are eclectic, eclecticism is merely a heuristic aid and must not be elevated to the status of a principle. Any principles that are used must be rigorously defined within a framework for pedagogic grammars and not simply taken over from another linguistic theory whose goals might be different. Pedagogic grammars must be developed which treat their own problems within their own methodology.

76-186 Smythe, P. C. and others. The best age for foreign-language training: issues, options and facts. Canadian Modern Language Review (Toronto), 32, 1 (1975), 10-23.

Research comparing the learning of adults and children in foreign-language courses is reviewed. The advantages generally assumed for children (physiological, motivational and length of time for learning) are not substantiated by the evidence [discussion]. It is unwise to model second-language training on firstlanguage acquisition because the nature of first-language acquisition is not fully understood and the two processes may operate according to quite different principles; second-language learning in a naturalistic, motivationally supportive environment cannot be used as a model, either, for learning in a structured, formalised classroom setting. Moreover, apart from the attitudinal/cultural benefits, there is little agreement as to any single set of linguistic goals appropriate to all FL programmes. 
PSYCHOL OGY OF LEARNING See also abstracts 76-164, -186

76-187 Baddeley, Alan D. and others. Word length and the structure of short-term memory. Journal of Verbal Learning and Verbal Behavior (New York), 14, 6 (1975), 575-89.

A number of experiments explored the hypothesis that immediate memory span is not constant, but varies with the length of the words to be recalled. Results showed that (1) memory span is inversely related to word length across a wide range of materials; (2) when number of syllables and number of phonemes are held constant, words of short temporal duration are better recalled than words of long duration; (3) span could be predicted on the basis of the number of words which the subject can read in approximately two seconds; (4) when articulation is suppressed, the word length effect disappears with visual presentation but remains when presentation is auditory. The results are interpreted in terms of a phonemically-based store of limited temporal capacity, which may function as an output buffer for speech production, and as a supplement to a more central working memory system.

76-188 Denhière, Guy. Mémoire sémantique, conceptuelle ou lexicale? (Semantic, conceptual or lexical memory?] Langages (Paris), 9, 40 (1975), 41-73.

Recent work on theories of comprehension of natural language by 20 American computer engineers is reviewed. For each model, the procedures of text analysis, memorisation and recall are summarised; its relevance to psychology is then assessed. Most models described postulate storage of concepts, not words, for long-term memory and owe something to Fillmore's case grammar for categorising the storage. 'Argument' and 'Proposition' as the stored units mark an advance. Postulation of labelled, directed links in the memory store is better than crude associationism. Research is now necessary into: relations between nouns and verbs; how novel experiences are processed for memorising; possible rules governing balance between economical storage and generative capacity of a long-term memory. [Diagrams, examples, references.]

76-189 Toulouse, Jean. Réflexions sur les motivations initiales des adultes qui apprennent ou réapprennent une langue étrangère. [Thoughts on the initial motivation of adults learning or re-learning a foreign language.] IUT Bulletin Pédagogique (Paris), 38 (1975), 17-30.

Since 50 per cent of adult learners abandon their modern-language courses, a questionnaire was sent to firms and education centres in the Aquitaine area to assess motivation of sample groups. Analysis showed that more men than women 
were learning a foreign language; the average age of the men was higher and they tended to belong to higher socio-professional groups. The majority of the women belonged to the 'clerical' group and were learning at education centres, whereas three quarters of the men took courses organised by their firms. Most adults were learning a language for a variety of reasons rather than one single motive: generally English was learned for utilitarian purposes and German and Spanish for disinterested reasons (cultural, social, pleasurable). Language courses arranged by firms were almost exclusively confined to English and attended by men. The latter appeared less highly motivated than students working on their own initiative at education centres, who did more work outside the classroom.

Under the automatic classification, where the element of subjectivity disappeared, English was characterised by interested motivation and German and Spanish by disinterested motivation. The same polarisation occurred between courses run by businesses and those at education centres. It seems that the old concept of English as a utilitarian language and of Spanish and German as culturally enriching languages still persists, and it is therefore not surprising that so many adults abandon their studies. [Transcript of questionnaire.]

\section{CONTRASTIVE ANAL YSIS See also abstract 76-184}

76-190 Helbig, G. Zur Rolle des kontrastiven Sprachvergleichs für den fremdsprachlichen Unterricht. [On the role of contrastive linguistic comparison for foreign-language teaching.] Jezyki obce w szkole (Warsaw), 19, 5 (1975), 270-7.

There is no agreement on whether and how contrastive linguistics can help language teaching: various possibilities are outlined here. Contrastive linguistics is not limited to comparing genetically related languages; it must be distinguished from language comparison by confrontation (konfrontativer Sprachvergleich) which not only investigates the differences but also the similarities between languages and is a theoretical discipline, related in an as yet undefined way with linguistic typology. There are two ways to compare/contrast languages: (1) by taking the target language as the more important and merely noting where it differs from the native language, or (2) by treating both languages equally. In the second case a metalanguage is necessary to talk about linguistic units. In any study, description must precede comparison. There are sometimes difficulties of comparability of items from different sub-systems in different languages. Psychological and linguistic methods of comparison and error analysis complement each other. Error analysis can only show where errors occur, but different methods of comparison must help language teaching by explaining why they occur. 


\section{ERROR ANAL YSIS See also abstract 76-215}

76-191 Kacowsky, Walter. Ergebnisse einer empirischen Untersuchung zur Fehlerhäufigkeit im Englischunterricht von der 5. Schulstufe bis zum Universitätseintritt. [The results of an empirical investigation into the error frequency in English teaching from the fifth school year up to university entrance.] Moderne Sprachen (Vienna), 19, 1/2 (1975), 1-20.

An analysis of error frequency in the learning of English was undertaken over a period of 22 years and a total of 19,181 written exercises, with the object of establishing a basis for prophylactic and corrective teaching. An error was defined as any deviation from the linguistic behaviour in the target language which native experts regarded as a prescriptive norm; the term was therefore not restricted to errors which interfere with communication. Interest in error analysis arises from a desire to test more objectively, to understand the learning process and to deal with interference between mother tongue and target language by the methods of contrastive linguistics. The broad scope of the investigation enabled factors attributable to individual learners to be increasingly eliminated. Three groups of learners were taken: the lower and upper school of selective schools and a group of university students. The error frequencies were analysed in categories drawn from practical teaching rather than linguistic theory. [Full breakdown of percentages of each type of error, for each age group.]

76-192 Ulijn, J. M. Analyse d'erreurs et compréhension écrite d'une langue seconde à buts vocationnels. [Analysis of mistakes and written comprehension in a second language learnt for vocational reasons.] ITL (Louvain), 28 (1975), 17-33.

Analyses of students' errors are important in any scientific evaluation of the content of a language course, particularly at adult level. Analysis of written comprehension is usually particularly poor; a machine (SHADOK) has therefore been developed which allows comprehension to be tested by physical reactions rather than verbally. A group of Dutch trainee engineers were required to carry out on the machine a series of instructions written in French. The factors influencing comprehension of a technical text in a foreign language are partly linguistic, partly dependent on technical background. The trainees were therefore grouped according to knowledge of French and year of course; it was found in pre-testing that both these factors influenced comprehension, but independently of each other. When the trainees were asked to respond to a graded series of non-technical instructions by manipulating the machine, a very specific analysis of the linguistic difficulties of comprehension of each of them was possible. [Transcript of the series of instructions used. Bibliography. Tables.] 
76-193 Zydatiß, Wolfgang. Eine Taxonomie von Fehlern in der englischen Wortstellung. [A taxonomy of errors in English word-order.] Linguistik und Didaktik (Munich), 6, 24 (1975), 304-24.

Errors can serve pedagogic goals and must be examined not only linguistically but also for extralinguistic causes. Written work of pupils who had been learning English for six years was examined for errors in word-order. Errors resulted from wrongly fronting objects (That point noticed some time ago the important Schopenauer), adverbs, using wrong inversion (Today has he written a letter), prepositional phrases (Before the speaker's chair are sitting the government), obligatory prepositional objects (On your help I was relying), the wrong placing of adverbs and the final position of the verb in subordinate clauses. The goal of a pedagogic grammar which uses error analysis should consist of providing the learner with insights into his errors and of giving him the means to overcome them. Drills could be used for this purpose, supplemented by a course in functional grammar to explain how errors occur.

\section{TESTING}

76-194 Folland, David and Robertson, David. Towards objectivity in group oral testing. English Language Teaching Journal (London), 30, 2 (1976), 156-67.

Group oral testing of the English of students siudying business and administration in Finland is described. The oral test is part of a wider test including composition and reading comprehension, and aims at a precise assessment of practical ability in spoken language. The group test is for a maximum of seven, who are tested in free discussion by two native English teachers; the stimulus is a taped report devised to cover a range of topics and with a suitable linguistic content. Arguments against oral testing are briefly answered and its advantages enumerated. [The marking system is described; adaptations of the test for other situations are possible.]

76-195 Levine, Josie. An outline proposal for testing communicative competence. English Language Teaching Journal (London), 30, 2 (1976), 128-35.

A test is proposed for middle-school children in multiracial classes in Britain, to assess their proficiency in using English for purposes of learning, thinking and communicating, and thus enable teachers to plan their future teaching; the model should also be applicable to tests of communicative competence in FL and SL situations. Language tests generally only test a small number of the 
combinations which make up the concept of full language skill; the required model would test not only a student's knowledge of the language and its contextual restraints but also the degree to which he can communicate effectively in specific circumstances. Objective marking against a grid is recommended, to reveal the degree of proficiency in a defined setting, with further discrete-item tests to specify in more detail students' lack of knowledge in any of the component language-skill areas, i.e. discrete-item tests backing up context tests. [Brief discussion of the test battery, including a rating sheet and possible test procedure.]

76-196 Löschmann, Martin and Löschmann, Marianne. Kontrollverfahren und -formen für das stille Lesen. [Testing procedures and test forms for evaluating silent reading.] Deutsch als Fremdsprache (Leipzig), 12, 4 (1975), 216-22.

Silent reading can only be tested through textual understanding. Such tests should encourage the student to do his reading more effectively. Results from tests involving translating, speaking and writing are only partiy relevant to evaluating silent reading. The degree of difficulty of the tests has to be increased progressively to keep pace with more complex texts. Depending on the level of proficiency, tests can be performed in class or at home. Extra-linguistic tests elicit non-linguistic reactions [examples] and tend to concentrate on the wider context rather than on details. For advanced learners a combination of linguistic and extra-linguistic tests is recommended. In the case of receptive tests, such as multiple-choice questions, the student has to decide if a given utterance agrees with the text he has read; the test thus acts at the same time as another exercise. [Disadvantages listed and modifications suggested.] Reproductive tests require the student to repeat parts of the text in answer to questions, which can be a superficial and formal exercise. Productive tests are meant to elicit independent, even divergent utterances, and represent the most demanding form of test, offering a wide range of procedures [some listed]. [Some other less common testing procedures are briefly described and the use of the mother tongue is discussed.]

76-197 Madson, Harold S. New alternatives in EFL exams, or 'How to avoid selling English short'. English Language Teaching Journal (London), 30, 2 (1976), 135-44.

As it is not yet possible to do away with the school leaving examinations in Africa, the most satisfactory alternative to existing examinations is felt to be one which combines the thorough, systematic evaluation of reading comprehension, structure and usage (a condensed version of one of the present examinations) with 
productive, integrative evaluation. The combination of integrative and discretepoint tests provides the broad scope and analytical features of the older allobjective test as well as a natural synthesising of language. The productive element should encourage communicative activities to return to the classroom. [Discussion of test content; references.]

76-198 Porter, D. Modified cloze procedure: a more valid reading comprehension test. English Language Teaching Journal (London), 30, 2 (1976), 151-5.

[Advantages and weaknesses of cloze procedure (CP) tests are discussed.] The main disadvantage of $\mathrm{CP}$ is that the student must not only comprehend but produce the required item. A modified $\mathrm{CP}$ provides a set of words for each gap and thus does not demand language production, merely recognition of the correct word. [The choice of suitable distractors is discussed.] [Example; references.]

76-199 Scheibner-Herzig, Gudrun and Pieper, Angela. Untersuchungen zur Struktur der Fremdspracheneignung bei neun-jährigen Schülern. [Investigations into the structure of the foreign-language aptitude of nine-year-old students]. Linguistische Berichte (Braunschweig), 39 (1975), 69-79.

In an attempt to predict performance in foreign-language learning, two tests were administered to 55 nine-year-old German elementary school pupils at the beginning and end of their first year of English instruction. The first one was the German version of Carroll's Modern Language Aptitude Test [5 subtests listed]. The test used at the end of the school year was an informal skill test consisting of 7 subtests [listed]. The subtests of the two tests were then correlated using the rank correlation coefficient according to Spearman. The rank of pupils in the group was established by the correlation values: high values tending to unity mean a favourable prediction of achievement, values around zero mean no prediction, and negative values indicate contradiction in the correlated subtests. [Detailed analysis is given of a matrix illustrating correlations as well as of predictions obtained from it.] Using partial rank correlation according to Johnson can make the results more precise. Success in some skills can be predicted more easily than in others. It also appears that in many cases more than one ability is involved in the prediction of performance in one skill. 
76-200 Smithies, Michael. Two methods of testing comprehension. English Language Teaching Journal (London), 30, 2 (1976), 144-51.

Two approaches to reading comprehension are described which aim to make students give serious consideration to linguistic details such as number, tense, etc. The first consists of a fairly technical text with a series of multiple-choice questions devised with the learners' particular difficulties in mind (in this case, Thai students) [many examples]. Results showed that there were few errors in the vocabulary section but as much as 92 per cent error with phrases or function words. With practice, students learned to analyse meaning more carefully. In the second method the different component sections can be mixed or separated in a different way [examples]. The methods effectively teach, as well as test, comprehension.

\section{COURSE DESIGN}

76-201 Alexander, L. G. Where do we go from here? A reconsideration of some basic assumptions affecting course design. English Language Teaching Journal (London), 30, 2 (1976), 89-103.

Some ideas are discussed which emanate from papers prepared for the Council of Europe. The relevance of textbook materials for the adult zero beginner is considered under three headings: (1) the overall framework of a course, (2) the role of situational teaching, and (3) the conduct of the lesson. Under (1), the idea of linking structural grading with a functional syllabus is endorsed [advantages enumerated]; under (2), situations suitable for language-teaching purposes are discussed, particularly $(a)$ 'limbo' situations, $(b)$ 'concrete' situations and (c) 'mythical' situations. Under (3), it is recommended that text-exploitation should not be confined to reporting but that 'transfer' should be built into every lesson to ensure that students can use language in a way relevant to their own experience [the 'personalised textbook'].

76-202 Galisson, Robert. Thèmes de prédilection et vocabulaires thématisés à charge incentive. [Preferred topics and vocabularies relating to motivationally weighted themes.] Etudes de Linguistique Appliquée (Paris), 18 (1975), 59-83.

A programme of applied lexicology designed to overcome the countermotivational banality of beginners' language courses is described. Successive and complementary studies are to be carried out: (1) among learner-populations to discover what topics interest them, (2) among socially comparable francophones to $\log$ the vocabulary they use to discuss these topics (a frequency list, a 
concordance of co-occurrences and word-clusters in a common semantic field); (3) concerning the social contexts in which the collected items would be used. [Discussion of terminology; review of earlier research; description of teaching materials; schematic tables showing relationships between centre of interest, preferred theme and total situation. Details of research tactics.]

MATERIALS DEVELOPMENT See abstracts 76-211, -221

\section{TEACHER TRAINING}

76-203 Whitton, David J. The migrant child and teacher preparation. Babel (Victoria, Australia), 11, 3 (1975), 21-8.

Nearly one person in three in Australia is an immigrant or a child of an immigrant. Although there is a strong case for bilingual education there is a shortage of bilingual teachers. As an immediate strategy, therefore, it is proposed that two main courses should be introduced into teacher-training programmes for the primary level, namely acculturation in the main cultures of the four major immigrant groups (Greek, Italian, Yugoslav and Turkish) together with a methodology for bicultural education and TESL. [Discussion, including the need for in-service training.] In addition, immigrant teachers should be encouraged to qualify. Perhaps the languages of the immigrants should be offered in secondary schools. [References.]

\section{TEACHING METHODS See also abstract 76-216}

76-204 Besse, Henri. De la pratique aux théories des exercices structuraux. [From the practice to the theories of pattern drills.] Etudes de Lin. guistique Appliquée (Paris), 20 (1975), 830.

Exercices structuraux inadequately renders 'pattern practice'. Bloomfield's 'patterns' were a researcher's concept; in FL teaching they would foster interferences. Bloomfield's 'structure' is not Saussure's structure. Harris' TG retrospectively systematises ad hoc pattern drills from FL teaching. Sapir's linguistic theory shows closer parallels with pattern practice, but his philosophy, like Pike's, puts language in a cultural context; published drills do not. Gouin, Palmer and Berlitz used patterns, and Fries (1952) reorganised them. Skinner's Verbal behavior does not mention pattern; gestalt psychology explains better than Skinner the theory behind pattern practice. [Bibliography.] 
76-205 Huot, Hélène. Exercices structuraux et enseignement de la langue maternelle. [Structure drills and mother-tongue teaching.] Etudes de Linguistique Appliquée (Paris), 20 (1975), 52-87.

Lesson materials for, say, Plan Rouchette, confuse types of language error, set up as norm an artificial written code and fail to teach sensitivity to register. A spoken register is not just the reading aloud of words from a written text. Theories of drilling run counter to observed maturation processes in children. Repetition does not result in production. Work proper to secondary school programmes is inappropriately drilled in primary lessons. No technique exists for measuring over-all language-handling in young children. Published drills are linguistically faulty. Teachers were ill-prepared to spot the inadequacies of the schemes.

\section{BILINGUAL TEACHING See also abstract 76-203}

76-206 Barik, Henri C. and Swain, Merrill. English-French bilingual education in the early grades: the Elgin study through grade four. Modern Language Journal (St Louis, Mo), 60, 1/2 (1976), 3-17.

The Elgin bilingual educational programme for English-speaking pupils, covering grades 1 to 4 , was begun in 1970 and is a partial French immersion (PFI) programme [details, including a previous evaluation in 1973]. The present evaluation revealed that (1) at the end of grade 1, pupils in the PFI programme were on a par with their peers in the regular English programme in English language and arithmetic skills, and did equally well in French - previously they did no better in French. (2) At the end of grade 2, PFI pupils were on a par with peers in English - previously they had fallen behind; and, though scoring higher in French than peers in the regular French programme, did less well than might have been expected in comparison with pupils in a total French immersion programme (TFI) - the same as previously. (3) At the end of grade 3, PFI pupils were on a par in English - previously at this stage they were still behind but were improving - and performed less well than TFI pupils in French, whereas previously they did equally well. [Analysis of results and discussion.] Improvements may be due to various pedagogical and organisational factors [discussion]. [References.]

CLASS METHODS See abstracts 76-212, -214, $-218,-222$

PRONUNCIATION See abstract 76-223 
READING See also abstracts $76-164,-192,-196,-200,-218$

76-207 Gray, John. 'The roots of reading'; a critical re-analysis. Research in Education (Manchester), 14 (1975), 33-47.

Criticisms are made of the recent NFER report The roots of reading: a study of twelve infant schools in deprived areas; in particular, of the views about the importance of (1) teaching reading early in the infant school, (2) 'instruction' in phonics and (3) an atmosphere that is 'organised' and 'structured' ('teacherdirected'). [Discussion and analysis of the recommendations.] It is concluded that there is little evidence based on classroom practice to support the claims made for 'organised' approaches to the teaching of reading; moreover, it is clear that there are heavy costs attached to certain 'traditional' strategies. Proposals for an early start and phonic instruction appear unexceptional until placed in context. The authors of the report argue that they are anxious to break out of the 'traditional/progressive' debate, but in so doing they appear to dismiss vital problems, namely the reconciling of flexible relationships with some element of organised learning.

76-208 Jackson, Mark D. and McClelland, James L. Sensory and cognitive determinants of reading speed. Joumal of Verbal Learning and Verbal Behavior (New York), 14, 6 (1975), 565-74.

Fast readers and average readers were tested on four tasks. Neither peripheral letter identification nor susceptibility of foveal letter identification to patterned masking differed between the two groups. However, fast readers appear to pick up more information per fixation on structured textual material, as indexed by a forced-choice test. Furthermore, the average fast reader had a greater span of apprehension for unrelated elements. It appears that faster readers are able to encode more of the contents of each fixation, whether or not higher order linguistic structure is present. The results are inconsistent with the view that reading speed is dependent solely on the reader's ability to infer or fill in missing information.

76-209 Neville, Mary H. and Pugh, A. K. Reading ability and ability to use a book: a study of middle school children. Reading (Manchester), 9, 3 (1975), 23-31.

The question of what is measured by a reading test, and whether it bears any relationship to the reader's performance in more realistic reading tasks, is 
considered. [Some recent criticisms of standardised tests of reading are noted.] A study was undertaken to discover how well children performed on an information location task, how they carried out the task and how their performance related to their performance on standardised tests of reading. Subjects, aged nine and ten, were videotaped as they looked in a book for answers to written questions about a story. The strategies used by the children were categorised as 'appropriate' (methodological use of index, table of contents, etc.), 'inappropriate' (trying to read straight through the book, or flicking through it in an apparently aimless way), or 'partly appropriate'. Results showed great diversity of performance among children with satisfactory reading performance as assessed by their school, and who did well on standardised tests of reading comprehension. There was no evidence that the cloze test, which is often considered to be a more 'realistic' task, was a better prediction of success in the book-use task. There was no relationship between pupils' performance on this task and the teacher variable. Despite the fact that a reading comprehension test does not appear to predict them, there are children of this age who can quite efficiently find factual information from a book, by using method and strategy to aid them in locating information. Children need to be given help on how to assess what a book might offer in relation to a given task. [References.]

\section{LITERATURE See abstract 76-217}

\section{INDIVIDUALISED INSTRUCTION}

76-210 Valdman, Albert. On the specification of performance objectives in individualized foreign language instruction. Modern Language Journal (St. Louis, Mo), 59, 7 (1975), 353-60.

Foreign-language teaching programmes featuring programmed instruction wrongly assume that a direct relationship exists between the attainment of proficiency in preparatory activities (drills and exercises) and the learner's ability to communicate. Performance objectives were introduced in order to verify the acquisition of proficiency at various stages; this led to the unfortunate neglect of higher aims. Misconceptions which limit the usefulness of performance objectives are: (1) a confusion between competence and performance, (2) inadequate identification of linguistic elements and (3) the erroneous assumption that linguistic elements correspond to learning steps [discussion]. Performance objectives have contributed little to the individualising of foreign language instruction or its improvement in general; they reflect traditional selection and ordering of subject-matter - reliance on behavioural models and neglect of simulated natural use of language. Any significant individualising of instruction 
requires profound changes in teachers' attitudes to the role of grammar in the preparation of materials and to the organisation of classroom activities.

\section{LANGUAGE LABORATORIES}

76-211 Campbell, Alistair. The preparation of materials for the language laboratory.. Modern Ianguages in Scotland (Aberdeen), 9 (1976), $17-41$.

[Reasons for using the language laboratory and ways of improving that use are outlined.] Suggestions for the writing of laboratory materials are given under the headings of listening activities and speaking activities (mechanical drills, open-ended exercises), together with multi-skill exercises for older pupils [examples]. [Appendixes include some exercise scripts, tables of suggested activities, and possibilities for testing.]

ADULTS See abstracts 76-189, $-203,-216$

\section{IMMIGRANTS See abstract 76-203}

ENGLISH See also abstracts 76-189, -191, -193/5, -197/8, -200/1, -203

76-212 Kugler, Walter. Strukturmerksäize. Ein Beitrag zur Fehlerkorrektur und -prophylaxe auf kontrastive Grundlage. [Structural mnemonic phrases. A contribution to the contrast-based correction and prevention of errors.] Neusprachliche Mitteilungen (Berlin), 28, 3 (1975), 132-40.

German students of English tend to make typical, recurring mistakes. A variety of ways to correct these and prevent their recurrence is discussed [examples]. The use of the contrastive mnemonic phrase is suggested as a new method of dealing with persistent errors. Such a phrase concentrates on one source of errors at a time. The grammatical rule violated by the error is implied in it rather than just illustrated; the phrase is used instead of the rule. By frequent active and passive repetition the phrase should become fixed in the student's mind. Structural differences between mother tongue and foreign language need not always be a source of error, and mnemonic phrases should only be formed for those contrasts that have been proved to present difficulties. These cases can be divided into a grammatical and lexical category. Firmly rooting mnemonic phrases in the student's memory is of overriding importance for the success of 
this approach. With this aim in mind, the formation and use of mnemonic phrases are described in detail [an appendix lists numerous examples].

76-213 Rivas, Michèle. Entrainement au débat public et à la négociation d'affaires en anglais. [Training students to use English for public discussion and business negotiations.] Langues Modernes (Paris), 69, $2 / 3$ (1975); 177-85.

The students in question already have an English core vocabulary in economics and commercial law. They learn first about different kinds of gathering, basic ways of negotiating agreements and the set expressions used in all committee work. Training in negotiation starts with role-playing short, complete meetings in which the English used is declarative, formal and neutral. The second phase introduces expressions of firm persuasion, reasoned exposition and emphatic stress. Lastly come expressions of compromise, strategies for allaying suspicion, contriving room for manoeuvre and delaying tactics. Each role-play is preceded by closely linked audio-lingual preparatory exercises based on 300 structures collected and noted for frequency and practical usefulness during real-life negotiations. Students are trained to react with Anglo-Saxon concepts, gestures and vocabulary to overtures and stimuli in French. The register of negotiation could be taught more widely.

76-214 Saftien, Volker. Zur systematischen Behandlung von phrasal/ prepositional verbs in Englischunterricht der Mittel- und Oberstufe. [The systematic treatment of phrasal/prepositional verbs in English lessons in the middle and upper school.] Neusprachliche Mitteilungen (Berlin), 28, 4 (1975), 219-29.

Phrasal/prepositional verbs in English are defined as verbs followed by one or more particles, e.g. to put up with. Such verbs are often neglected or badly taught to German pupils of English and cause severe learning difficulties. Since these verbs are widely used by native speakers, it is essential that foreign learners should have an intensive and systematic grounding in about 60 such verbs during eight to ten lessons, spread over a period of 12 weeks with two-week periods of reinforcement.

The following skills should be systematically introduced: (1) the literal and idiomatic usage of identical particle verbs (comparison may be made with German prefixed verbs); (2) the replacement of verbs of romance origin by synonymous particle verbs to facilitate learning; (3) the ability to differentiate between the transitive and intransitive use of particle verbs; (4) the correct stressing of the verb and the placing of the object in order to distinguish between phrasal and prepositional verbs; (5) deciding whether such verbs are 
followed by a gerund or an infinitive, and (6) handling verbs with several particles from a semantic, phonological and syntactical viewpoint. [Many examples. Bibliography.]

76-215 Szala, Alina and Horoszkiewicz, Eleonora. O lepse rozumienie angielszczyzny mówionej. [Towards a better understanding of spoken English.] Jezykí obce w szkole (Warsaw), 19, 4 (1975), 210-13.

A review of the approach to the teaching of English in Polish schools at secondary level is necessary, since at present it is too book-oriented, and does not prepare students adequately for university language courses. In order to define specific problems of oral comprehension, a one-year study was undertaken: dictation exercises were given to first-year students to test their aural comprehension. A detailed analysis was made of the types of difficulties [examples].

76-216 Trocmé, Hélène. L'anglais enseigné aux adultes; recherche d'une solution aux problèmes linguistiques et méthodologiques. [English for adults; seeking a solution to linguistic and methodological problems.] IUT Bulletin Pédagogique (Paris), 38 (1975), 31-6.

The author's classes use All's well which avoids the rigid memorising of earlier audio-visual courses. It extends the auditory training period: students store a range of situations, gestures, remarks; acquire a sense of the overall language structure; look for the relationships between sentences and between speakers. Comprehension is not expected immediately, but allowed to grow. Students' first remarks in the FL are spontaneous, not imitative; they are personally involved. Accuracy is cultivated in another phase. Attention is focused on students as language users within a social context; problems of linguistics are related to this situation, and not the other way round.

76-217 Zozulya, D. G. Чтение общественно-политической литературы в старших класcах. [The reading of socio-political literature in senior classes.] Иностранные лзыкив иколе (Moscow), 6 (1975), 65-8.

The reading of socio-political literature in the senior classes performs the following functions: (1) broadening the political outlook of the pupils, enabling them better to understand and evaluate international events; (2) the broadening of political vocabulary, both active and passive; (3) directed development of reading without translating, of the spoken and written word, and of the ability to translate and work with a dictionary; (4) acquaintance with 'civilisation' 


\section{LAINGAGE LEARNING AND TEACHING}

materials and with the struggle of the working class for political and economic rights.

A questionnaire was prepared to find out which papers were read by pupils, and which topics interested them. In schools where English was used as a medium for teaching other subjects, the replies to the questionnaire were similar to those in an ordinary school. 'Theatre and Cinema' was the most popular topic, then 'Chronicle of Sport'; 'News from the Foreign Press' (from the newspaper Moscow News) was also high on the list. A knowledge of the interests of the pupils helps in the realisation of the practical task of mastering a foreign language.

FRENCH See also abstracts 76-192, -202, -205, -211

76-218 Moirand, Sophie. Le rôle anaphorique de la nominalisation dans la presse écrite. [The anaphoric role of nominalisation in journalism.] Langue Française (Paris), 28 (1975), 60-78.

An understanding of anaphora is a major help to students deciphering news articles. 'Undoctored' articles are presented for elicitation of key nouns and verbs. The class is encouraged to muse aloud; an overhead projector can conceal nominalisations for the class to infer them from verbal syntagms elsewhere in the paragraph. Later, articles are more opaque; the class invents a nominalisation to act as a 'conceptual' anaphora closing a paragraph. [Work on titling, notetaking, précis and reports.] Studies in register assess the degree of subjectivity in nominalisations. Extensive work by linguists on nominalisation provides an excellent framework for teachers.

\section{GERMAN See also abstracts 76-189, $-196,-199$}

76-219 Latour, Bernd. Die Rolle der Wortbildung im studienbegleitenden Deutschunterricht. [The role of word formation in the auxiliary teaching of German to foreign students.] Zielsprache Deutsch (Munich), 4 (1975), 7-13.

Foreign university students learning German in addition to studying at a German university must be enabled to function within the university, do assignments, write exams, and, above all, understand learned texts. [Some grammatical characteristics of learned German are listed.] Special attention should be given to productive word-formation patterns, in particular those using adjectives as one element. In learned German many key words are ad hoc formations, too new or transitory to be found in any dictionary. For this reason teaching word-formation patterns and paradigms can be of more use than 
teaching isolated units of vocabulary. The transformational relation between an adjectival compound and an explicative sentence are of great value in the teaching process, provided certain conditions are observed [discussion]. Fleischer's Wortbildung der deutschen Gegenwartssprache made an attempt to systematise the adjectival compounds and arrived at three groups based on transformation. [List and discussion: possible improvements and new categories are suggested.] Suggestions about suitable teaching material and points of methodology are given.

\section{ITALIAN}

76-220 Berretta, Monica. Fra linguistica e didattica dellitaliano: preposizioni e gruppi preposizionali. [On linguistics and the teaching of Italian: prepositions and prepositional phrases.] Studi italiani di linguistica teorica ed applicata (Rome), 3, 3 (1974), 293-367.

The choice of a theoretical model (or grammar) must depend on the aims of the teaching. As some Italian school grammars show, there is the danger of altering the technical side (e.g. terminology) without changing the traditional aims and methods. Some school grammars are tested as to the theory and practice of teaching prepositions and prepositional phrases. A simple but powerful syntactic model is proposed for mother-tongue teaching, particularly prepositional phrases. It emphasises practical activities for pupils based on the production of linguistic structures with special attention to the semantic level. [Brief typology of exercises and suggestions for research.]

\section{SPANISH See also abstract 76-189}

76-221 Tierney, Ian. Spanish studies for the less able pupil in S3/S4. Modern Languages in Scotland (Aberdeen), 9 (1976), 50-9.

A working party of Lanarkshire teachers considered the provision of material suitable for non-certificate pupils of Spanish in third and fourth year secondary school. It was decided that the course would consist of a series of units of different forms but with an overall pattern; some would have more language content than others but in general the linguistic content would be minimal, the move being away from the teaching of grammar and memory work. [Summary of topics, including Travelling to Spain, Carreteras y Calles, Sport, Fiestas; extracts from materials are given.] 


\section{RUSSIAN}

76-222 Crispin, Anthony. An experiment in group teaching. Modem Languages in Scotland (Aberdeen), 9 (1976), 60-81.

An experimental approach to group teaching is described. It was developed in a boys' comprehensive school and the course led in four years to GCE O level Russian. Purpose-built teaching materials were found to be essential. [Division into two ability groups; classroom arrangement; lesson plans; visual aids; texts of various kinds; homework; testing and evaluation. Examples and illustrations.]

76-223 Lake, J. Joseph. Grammar explanation in terms of sentence stress. Slavic and East European Journal (Urbana, Ill), 19, 2 (1975), 166-73.

Sentence stress is invaluable for teaching word order and certain other grammatical points. It serves to highlight the focus of a sentence, which in Russian normally takes final position. Thus English stress indicates Russian normal word order: Madaет снеz 'Some snow is falling'. Focus also helps in explaining marked word order. The notion can be introduced in question-answer sequences as it is that which is asked about and repeated in the answer: Ву были в meamp? Да был. Focus determines the position of $\Omega u$ (in questions, indirect questions and, most important, echo questions) and the position of the other clitics. It also distinguishes moxe and maкжe (moxce must bear sentence stress). [Examples and suggestions for drills throughout.]

76-224 Rassudova, O.P. Aspectual meaning and aspectual context in the teaching of Russian verbal aspect. Slavic and East European Journal (Urbana, Ill), 19, 2 (1975), 139-44.

Aspect in Russian is a grammatical opposition in which the perfective is the marked member. The perfective is more fixed semantically, having the single basic meaning of one-time, completed action perceived in its unity. The imperfective has three basic meanings: action in progress, repeated action and general validity. These three meanings are realised in different aspectual contexts, which condition one or other meaning. Even fluent speakers make mistakes in omitting contextual elements, and utterances may be misinterpreted [examples]. The teacher should therefore link model contexts with each aspect, as patterns for large numbers of utterances. He should progress from the features which separate the aspects to those which distinguish the basic meanings of the imperfective, before tackling the features which bring the aspects into competition (for they are not in constant and complete contrast.) 